NASA/TM-2005-213981

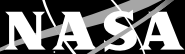

NASA Radioisotope Power Conversion Technology NRA Overview

David J. Anderson

Glenn Research Center, Cleveland, Ohio 
Since its founding, NASA has been dedicated to the advancement of aeronautics and space science. The NASA Scientific and Technical Information (STI) Program Office plays a key part in helping NASA maintain this important role.

The NASA STI Program Office is operated by Langley Research Center, the Lead Center for NASA's scientific and technical information. The NASA STI Program Office provides access to the NASA STI Database, the largest collection of aeronautical and space science STI in the world. The Program Office is also NASA's institutional mechanism for disseminating the results of its research and development activities. These results are published by NASA in the NASA STI Report Series, which includes the following report types:

- $\quad$ TECHNICAL PUBLICATION. Reports of completed research or a major significant phase of research that present the results of NASA programs and include extensive data or theoretical analysis. Includes compilations of significant scientific and technical data and information deemed to be of continuing reference value. NASA's counterpart of peerreviewed formal professional papers but has less stringent limitations on manuscript length and extent of graphic presentations.

- TECHNICAL MEMORANDUM. Scientific and technical findings that are preliminary or of specialized interest, e.g., quick release reports, working papers, and bibliographies that contain minimal annotation. Does not contain extensive analysis.

- CONTRACTOR REPORT. Scientific and technical findings by NASA-sponsored contractors and grantees.
- CONFERENCE PUBLICATION. Collected papers from scientific and technical conferences, symposia, seminars, or other meetings sponsored or cosponsored by NASA.

- SPECIAL PUBLICATION. Scientific, technical, or historical information from NASA programs, projects, and missions, often concerned with subjects having substantial public interest.

- TECHNICAL TRANSLATION. Englishlanguage translations of foreign scientific and technical material pertinent to NASA's mission.

Specialized services that complement the STI Program Office's diverse offerings include creating custom thesauri, building customized databases, organizing and publishing research results ... even providing videos.

For more information about the NASA STI Program Office, see the following:

- Access the NASA STI Program Home Page at http://www.sti.nasa.gov

- E-mail your question via the Internet to help@sti.nasa.gov

- Fax your question to the NASA Access Help Desk at 301-621-0134

- Telephone the NASA Access Help Desk at 301-621-0390

- Write to:

NASA Access Help Desk

NASA Center for AeroSpace Information 7121 Standard Drive

Hanover, MD 21076 
NASA/TM-2005-213981

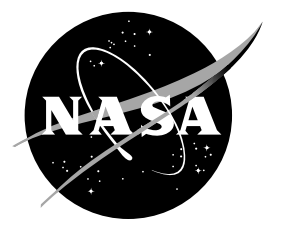

\section{NASA Radioisotope Power Conversion Technology NRA Overview}

David J. Anderson

Glenn Research Center, Cleveland, Ohio

Prepared for the

Space Technology and Applications International Forum (STAIF-2005)

sponsored by the University of New Mexico's Institute for

Space and Nuclear Power Studies (UNM-ISNPS)

Albuquerque, New Mexico, February 13-17, 2005

National Aeronautics and

Space Administration

Glenn Research Center 


\section{Acknowledgments}

The results and findings presented here are based on work funded by the National Aeronautics and Space Administration (NASA) under the Radioisotope Power Conversion Technology NASA Research Announcement NRA 02-OSS-01 issued through the Science Mission Directorate, Project Prometheus Program. The author would like to acknowledge the assistance of Jean-Pierre Fleurial and Jeff Snyder, Jet Propulsion Laboratory; and Roy Tew,

Wayne Wong, and Thomas Kerslake, NASA Glenn Research Center, and the rest of the RPCT NRA contract and technical monitors for their inputs and review of this paper.

This report contains preliminary

findings, subject to revision as analysis proceeds.

Available from

NASA Center for Aerospace Information 7121 Standard Drive

Hanover, MD 21076
National Technical Information Service 5285 Port Royal Road Springfield, VA 22100 


\title{
NASA Radioisotope Power Conversion Technology NRA Overview
}

\author{
David J. Anderson \\ National Aeronautics and Space Administration \\ Glenn Research Center \\ Cleveland, Ohio 44135
}

\begin{abstract}
The focus of the National Aeronautics and Space Administration's (NASA) Radioisotope Power Systems (RPS) Development program is aimed at developing nuclear power and technologies that would improve the effectiveness of space science missions. The Radioisotope Power Conversion Technology (RPCT) NASA Research Announcement (NRA) is an important mechanism through which research and technology activities are supported in the Advanced Power Conversion Research and Technology project of the Advanced Radioisotope Power Systems Development program. The purpose of the RPCT NRA is to advance the development of radioisotope power conversion technologies to provide higher efficiencies and specific powers than existing systems. These advances would enable a factor of 2 to 4 decrease in the amount of fuel and a reduction of waste heat required to generate electrical power, and thus could result in more cost effective science missions for NASA. The RPCT NRA selected advanced RPS power conversion technology research and development proposals in the following three areas: innovative RPS power conversion research, RPS power conversion technology development in a nominal $100 \mathrm{~W}_{\mathrm{e}}$ scale; and, milliwatt/multi-watt RPS (mWRPS) power conversion research. Ten RPCT NRA contracts were awarded in 2003 in the areas of Brayton, Stirling, thermoelectric (TE), and thermophotovoltaic (TPV) power conversion technologies. This paper will provide an overview of the RPCT NRA, a summary of the power conversion technologies approaches being pursued, and a brief digest of first year accomplishments.
\end{abstract}

\section{Radioisotope Power Conversion Technology (RPCT) Overview}

The objective of the National Aeronautics and Space Administration's (NASA) Radioisotope Power Systems (RPS) Development program is to develop nuclear power conversion technologies that would improve the effectiveness of space science missions. The NASA Research Announcement (NRA 02-OSS-01, "Research Opportunities in Space Science 2002" entitled "Radioisotope Power Conversion Technology," 13 August 2002) is an important mechanism through which research and technology activities are funded under the Advanced Power Conversion Research and Technology project of the Advanced Radioisotope Power Systems Development program. The objective of the RPCT NRA is to advance the development of radioisotope power conversion technologies to provide higher efficiencies and specific powers than existing systems. These advances would enable a factor of 2 to 4 decrease in the amount of fuel and a reduction of waste heat required to generate electrical power, and thus could result in more cost effective science missions for NASA. The RPCT NRA selected advanced RPS power conversion technology research and development proposals in the following three areas: innovative RPS power conversion research, RPS power conversion technology development in a nominal $100 \mathrm{~W}_{\mathrm{e}}$ scale; and, milliwatt/multi-watt RPS (mWRPS) power conversion research. Ten RPCT NRA contracts were awarded in 2003 in the areas of Brayton, Stirling, thermoelectric (TE), and thermophotovoltaic (TPV) power conversion technologies. This paper will provide an overview of the RPCT NRA, a summary of the power conversion technologies approaches being pursued, and a brief digest of first year accomplishments.

\section{Summary of the Need and Future of Advanced RPS in Space}

Radioisotope power systems are capable of producing decades of both heat and electricity under the harsh deep space conditions where the sunlight is too faint to power a spacecraft. NASA and the U.S. Department of Energy (DOE) (and its predecessors) have used radioisotope power systems reliably in space exploration for more than 
35 years to serve this purpose (see Table 1). To date, the United States has launched 25 missions involving 44 Radioisotope Thermoelectric Generators (RTGs). RTGs have demonstrated continuous power for 30-plus years, and have been proven safe, reliable and maintenance free (DOE, 2002).

NASA has identified a number of potential missions that can best or only be undertaken using radioisotope power and/or heat sources. Future potential planetary missions such as Titan Explorer, Europa Lander, or Mars Landers require RPS that are mass and volume efficient, and that can work reliably for long periods of time in vacuum and planetary atmospheres. (NASA, 2002) The future potential missions also require a technology that can be scalable from a few watts to a few hundred watts as requirements vary from mission to mission. To enable the next ambitious steps in exploration of our Solar System using safe, cost effective spacecraft, NASA and DOE are developing advanced, high-efficiency radioisotope power convertors (NASA, 2003) (see Table 1). Several radioisotope power conversion technologies for space applications are under investigation through RPCT NRA contracts. Safety and reliability are key factors in determining the possible value of each technology in space missions. These technologies involve both more efficient conversion of heat into electricity and reduced system mass. The higher efficiencies of these new technologies mean that future spacecraft may require less Pu- 238 than current RTGs typically use. This makes these new space power technologies highly attractive due to lower weight and less radioactive material for the same power output. In addition, these power conversion designs must minimize electromagnetic interference and vibration to enable scientific experiments.

TABLE 1.-PAST, PRESENT, AND FUTURE OF RADIOISOTOPE POWER SYSTEMS

\begin{tabular}{|c|c|c|c|c|c|}
\hline & Past & Present & Under De & elopment & RPCT NRA \\
\hline Application & $\begin{array}{c}\text { SNAP-27 } \\
\text { (Apollo) } \\
\text { SNAP-19 } \\
\text { (Viking, Pioneer) } \\
\text { MHW RTG } \\
\text { (Voyager) }\end{array}$ & $\begin{array}{c}\text { GPHS RTG } \\
\text { (Galileo, Cassini) }\end{array}$ & $\begin{array}{l}\text { Multi-Mission } \\
\text { RTG (MMRTG) }\end{array}$ & $\begin{array}{l}\text { Stirling } \\
\text { Radioisotope } \\
\text { Generator } \\
(S R G)\end{array}$ & TBD \\
\hline $\begin{array}{c}\text { Power } \\
\text { Conversion } \\
\text { Approach }\end{array}$ & Thermoelectrics & Thermoelectrics & Thermoelectrics & Stirling & $\begin{array}{c}\text { Free-Piston Stirling } \\
\text { Turbo-Brayton } \\
\text { Segmented Thermoelectrics } \\
\text { Thermophotovoltaics } \\
\end{array}$ \\
\hline $\begin{array}{l}\text { Specific Power } \\
\left(\mathrm{W}_{\mathrm{e}} / \mathrm{kg}\right)\end{array}$ & 3 to 4 & 5.4 & 3 to 4 & 3.3 to 4 & 5 to 10 \\
\hline $\begin{array}{c}\text { System } \\
\text { Efficiency }\end{array}$ & 6 percent & 7 percent & 6 percent & 23 percent & 12 to 35 percent \\
\hline Power $\left(\mathrm{W}_{\mathrm{e}}\right)$ & $\begin{array}{l}\text { SNAP19 40 } \\
\text { MHW } \sim 160\end{array}$ & 285 & $\geq 110$ & $\geq 110$ & $\begin{array}{l}\sim 100 \text { Class } \\
\text { Scalable }\end{array}$ \\
\hline Life (years) & --- & $\geq 15$ & $\begin{array}{c}10 \text { to } 14 \text { (Space) } \\
>3 \text { (Mars) }\end{array}$ & $\begin{array}{c}10 \text { to } 14 \text { (Space) } \\
>3 \text { (Mars) }\end{array}$ & $\geq 14$ Years \\
\hline Environment & Space & Space & Multi-Mission & Multi-Mission & Multi-Mission \\
\hline
\end{tabular}

\section{Summary of How an RPS Works}

A radioisotope power system converts the heat emitted from the decay of the radioactive isotope plutonium238 , which is unusable for nuclear weapons, into the electricity required to power a spacecraft. These power systems are ideal for spacecrafts that are too far from the sun to effectively use solar energy conversion, such as, the Galileo mission to Jupiter and the recently launched Cassini mission to Saturn. In addition to radioisotope power systems, radioisotope heater units (RHUs) use the heat generated by plutonium-238 to keep a spacecraft's instruments warm and within their designed operating temperatures (DOE, 1990).

Heat is supplied to the convertor from a DOE General Purpose Heat Source (GPHS) module, containing approximately 600 grams of Plutonium dioxide that produces about 250 watts of thermal power. However, only a portion of the heat energy supplied to the power convertor is converted into electricity. The remainder is rejected as waste heat and is typically used by the spacecraft to maintain key electronics and instruments within their operating temperature range (see Fig. 1). NASA is responsible for RPS convertor technology development up to component 


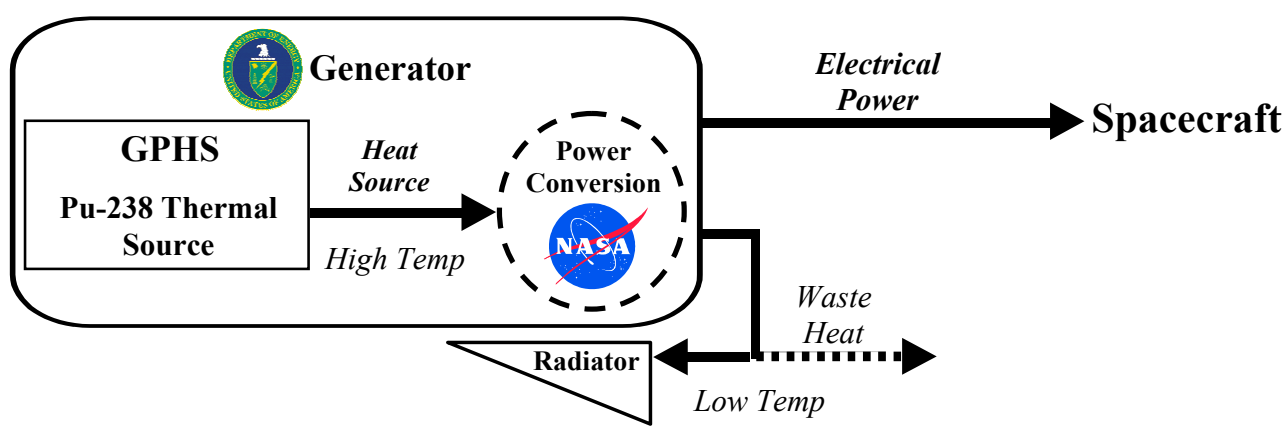

Figure 1.-Anatomy of a Radioisotope Power System.

TABLE 2.-THE GPHS/RTG PERFORMANCE PARAMETERS AS SPECIFIED IN THE RPCT NRA

\begin{tabular}{|l|l|}
\hline \multicolumn{2}{|c|}{ Performance Parameters for GPHS/RTG } \\
\hline System Efficiency & 7 percent \\
\hline Power Conversion Device Efficiency & 8 percent \\
\hline Specific Power & $5 \mathrm{~W}_{\mathrm{e}} / \mathrm{kg}$ (Beginning of Life, BOL) \\
\hline Specific Power & $\begin{array}{l}4 \mathrm{~W}_{\mathrm{e}} / \mathrm{kg} \text { (BOL }+10 \text { years) } \\
\text { In addition to offering advancements over State of Practice, it is also required } \\
\text { that non-milliwatt RPS have an output voltage of } 28 \mathrm{~V}_{\mathrm{DC}} .\end{array}$ \\
\hline
\end{tabular}

and/or breadboard validation in a relevant environment (Technology Readiness Level TRL 5). And DOE is responsible for generator system development beyond TRL 5. The RPCT NRA technology development is inside the dashed line in Figure 1.

Advanced RPS designs will interface with GPHS modules, or a de-rated GPHS. For the nominal, $100 \mathrm{~W}_{\mathrm{e}}$ level RPS effort, the proposed power conversion technologies will offer advancements over the State-of-Practice GPHS/Radioisotope Thermoelectric Generator (RTG) performance parameters (see Table 2) as specified in the RRCT NRA (NASA, 2002). A de-rated GPHS can be used for scaling to low power levels (less than the nominal $100 \mathrm{~W}_{\mathrm{e}}$ ). While the milliwatt Radioisotope Power Systems must interface with either one or more Radioisotope Heater Units (RHUs) or with a de-rated GPHS module. Descriptions of the GPHS and RHU can be found at http://nuclear.gov/ under "Program Offices," "Space and Defense Power Systems."

\section{Advanced RPS Project Goal}

The goal of the Advanced RPS Project is to advance, via research and technology development, promising power conversion technologies for potential application in RPS beyond current 1st-generation Multi-mission Radioisotope Thermoelectric Generators (MMRTG) and Stirling Radioisotope Generators (SRG) that are being developed for potential use on the 2009 Mars Science Laboratory (MSL) mission.

- Viability is characterized by safety, performance (power conversion efficiency and specific power $\left(\mathrm{W}_{\mathrm{e}} / \mathrm{Kg}\right)$, reliability and long life (>14 yrs with well understood degradation), weight and volume, development risk, scalability, operational capability, and system integration

- Success depends on providing a significant improvement over state-of-practice RPS and meeting the needs of future mission designers

\section{Radioisotope Power Conversion Technology (RPCT) Areas}

The objective of the Radioisotope Power Conversion Technology (RPCT) NASA Research Announcement (NRA) is to advance the development of radioisotope power conversion technologies to provide higher efficiencies and specific powers than existing systems. The RPCT NRA selected advanced RPS power conversion technology 
research and development proposals in the following three areas: innovative RPS power conversion research, RPS power conversion technology development in a nominal $100 \mathrm{~W}_{\mathrm{e}}$ scale; and, milliwatt/multi-watt RPS (mWRPS) power conversion research (NASA, 2002).

Innovative RPS Power Conversion Research

RPS Power Conversion Technology

Development

Milliwatt/Multi-watt RPS (mWRPS) Power Conversion Research
- Research will be conducted on a broad range of innovative space application RPS power conversion technology concepts, for the development of very low Technology Readiness Level (TRL) research activities. At the end of the 3 years, it is expected that the technology will be developed to a TRL level of 2-3 (see Table 3 below).

- Development will be conducted on advance RPS technologies from a basic/applied research level to verification of power conversion device and/or breadboard validation. At the 3 years, it is expected that the technologies will be at TRL 4-5.

- Research will be conducted on advanced power conversion options for milliwatt/multi-watt-level power converters compatible with heat sources designed for space applications. At the end of the 3 years, it is expected that the technology will be developed to a TRL level of 2-3.

TABLE 3.-THE NASA TECHNOLOGY READINESS LEVELS

\begin{tabular}{|c|l|}
\hline TRL & \multicolumn{1}{c|}{ Accomplishment } \\
\hline 5 & Component and/or breadboard validation in relevant environment. \\
\hline 4 & Component and/or breadboard validation in laboratory environment. \\
\hline 3 & Analytical and experimental critical function and/or characteristic proof of concept. \\
\hline 2 & Technology concept and/or application formulated. \\
\hline 1 & Basic principles observed and reported. \\
\hline
\end{tabular}

\section{Introduction to the RPCT Power Conversion Technologies}

Four power conversion technologies are being explored under RPCT: dynamic technologies like Brayton and Stirling, and static technologies like thermoelectric (TE) and thermophotovoltaic (TPV). The dynamic systems have moving parts that transform heat into mechanical energy, which in turn is used to generate electricity. The dynamic isotope power systems are more efficient ( $\sim 20$ to 35 percent) in converting heat into electricity than the static power conversion technologies. While the static systems have a benefit of having no moving parts, they also have lower efficiencies ( $\sim 10$ to 20 percent) than the dynamic systems. Both the advanced static and dynamic power conversion approaches have projections for specific power of between 5 to $10 \mathrm{~W}_{\mathrm{e}} / \mathrm{kg}$. All four power conversion approaches use heat from the GPHS to heat the hot side of the device, and the cold of space (or an atmosphere) to produce a low temperature at the cold side of the device.

A thermoelectric (TE) power convertor is a static energy conversion system that turns heat directly into electricity utilizing the Seebeck effect. A thermoelectric couple is produced when the junctions of a circuit formed from two dissimilar materials (such as n- and p-type semiconductors) are connected electrically in series but thermally in parallel and the junctions are maintained at different temperatures; the open circuit voltage developed is proportional to the combined Seebeck coefficient of the two materials and the temperature differential across the junctions. A TE convertor contains many thermoelectric couples (or thermocouples). Such thermoelectric couples are typically arrayed in a series/parallel configuration to produce the desired output power characteristics. The efficiency and therefore power output is a function of the temperature of each junction and thermoelectric material properties. High conversion efficiency requires TE materials that possess a combination of low thermal conductivity, low electrical resistivity and large Seebeck coefficient values.

Thermophotovoltaic (TPV) energy conversion is a static process whereby infrared photons, emitted by a hot surface, are converted to electrical energy by a photovoltaic (PV) device. TPV convertors use advanced PV cells, spectrally-tuned to optimize the conversion of the emitted photon flux. Spectral control, including selective emitter, PV cell, and filter characteristics, are key to high performance.

A Free-piston Stirling engine operates on the Stirling thermodynamic cycle and has two reciprocating components, the displacer and the piston. The displacer shuttles the working gas, typically Helium, between the hot 
expansion space, and the cold compression space through a series of heat exchangers. The regenerator improves the efficiency of the cycle by storing heat as the hot gas flows toward the cooler, and heats the cool gas as it flows toward the heater conserving energy. The pressure waves created by piston and displacer motion, and the heating and cooling of the gas, cause sustained piston and displacer reciprocating motions (free-piston designs can provide self-starting oscillations, once an adequate temperature differential is achieved). A linear alternator attached to the piston converts this mechanical motion into electrical power.

A Brayton power converter consists of a turbine, compressor, alternator and separate heat exchangers for the heat source and the waste heat rejection. An additional heat exchanger, called a recuperator, is often used to transfer heat within the cycle and improve cycle efficiency. An inert gas, typically a mixture of helium and xenon, is used as the working fluid. The working fluid undergoes a thermodynamic cycle; the fluid is heated in the heat source heat exchanger, expanded through the turbine, passed through a gas cooler (rejecting waste heat) and pressurized by the compressor before re-entering the heat source heat exchanger to be heated again. A rotary alternator attached to the turbine shaft produces alternating current (AC) electrical output.

\section{The Radioisotope Power Conversion Technology (RPCT) Efforts}

Ten RPCT NRA contracts were awarded in the areas of Thermoelectrics, Thermophotovoltaic, Stirling, and Brayton power conversion technologies in the research areas identified in Table 4. Each NRA contract is divided into 3 one-year periods. For each of the ten RPCT NRA contracts, Phase I accomplishments, as presented by the contractors, are summarized below, along with a short description of their project

TABLE 4.--RPCT NRA NUMBER AND DISTRIBUTION OF CONTRACTS PER FOCUS AREA

\begin{tabular}{|c|c|c|}
\hline Focus Areas & $\begin{array}{c}\text { Nominal } \sim \mathbf{1 0 0} \mathbf{W}_{\mathrm{e}} \text {-scale applications } \\
\left(1 \text { to } 100 \mathrm{~W}_{\mathrm{e}} \text { scalable }\right)\end{array}$ & $\begin{array}{c}\text { Milliwatt-scale (mW) applications } \\
\left(\sim 10 \text { to } 100 \mathrm{~mW}_{\mathrm{e}}\right)\end{array}$ \\
\hline $\begin{array}{c}\text { Research } \\
\mathrm{TRL} \leq 3 \text { Proof of concept }\end{array}$ & $\begin{array}{c}1 \text { Thermoelectric }(T E) \\
1 \text { Thermophotovoltaic }(T P V) \\
1 \text { Stirling }\end{array}$ & 2 Thermoelectric $(T E)$ \\
$\begin{array}{c}\text { Development } \\
\mathrm{TRL} \leq 5 \text { Component/ breadboard in } \\
\text { relevant environment }\end{array}$ & $\begin{array}{c}1 \text { Thermoelectric }(T E) \\
\text { Thermophotovoltaic }(T P V) \\
1 \text { Stirling } \\
1 \text { Brayton }\end{array}$ & None funded \\
\hline
\end{tabular}

\section{Thermoelectrics (TE)}

The Teledyne Energy Systems/Boeing Segmented Thermoelectric Generator development effort evaluates the combination of a number of proven state-of-practice telluride materials in a segmented couple to take advantage of the high efficiencies available from Bi-Te materials at low temperatures with the demonstrated PbTe and TAGS performance at higher temperatures. This approach moves the heat source clad material well away from its high temperature limits for long term operation. First year achievements include:

- A Phase I baseline BiTe/PbTe - BiTe/TAGS/PbSnTe compact module/mini-couple (4 by 4 in. with 108 couples) design was completed, and projecting $20 \mathrm{~W}_{\mathrm{e}}$ at $5 \mathrm{~V}$ using single GPHS with BOL system efficiency of 8 percent $\left(\mathrm{T}_{\text {hot }}=538^{\circ} \mathrm{C}, \mathrm{T}_{\text {cold }}=121^{\circ} \mathrm{C}\right)$

- Demonstrated co-hot pressing of TAGS-85 and PbSnTe, and other advanced thermoelectric materials development efforts making progress

The MIT/Boston College/JPL Si-Ge Nanocomposites in Thermoelectrics research effort is researching a novel approach for using nano-structured materials to improve significantly the performance of bulk thermoelectric materials. The use of SiGe-based nano-components to reduce phonon transport promises not to adversely affect the electrical properties. It thus has a strong chance to increase the conversion efficiency from the current 8 percent state-of-the-art to 14 to 16 percent. First year achievements include: 
- Successful synthesis of Si and Ge nanowires and nanoparticles

- Successfully achieved bulk sample size of nano Si micro Ge composite

- Nanostructures offer promise for increasing ZT (TE Figure-of-Merit), which leads to increase efficiency

- Very significant reduction in thermal conductivity of Si-Ge nanocomposites

- Developed first model for the thermal conductivity of 2D periodic nanocomposites

\section{Milli-Watt Thermoelectrics (mW)}

The Teledyne Energy Systems/Research Triangle Institute Superlattice Thermoelectric Power Systems research effort is to develop and test a cascaded thin-film Superlattice BiTe and PbTe/TAGS-PbSnTe thermoelectric converter module. This arrangement is expected to improve power conversion efficiency from 4 percent to 12 percent and reduce plutonium requirements by 50 to 70 percent. Teledyne Energy Systems is leading the effort with Research Triangle Institute (RTI) as an important team member. First year achievements include:

- Developed a co-hot pressing process for fabrication of segmented TAGS-PbSbTe

- Identified and evaluated several commercial ceramic adhesive and low temperature glass formulations for bonding thermoelectric material slices

- Fabricated several linear array multicouples

- Superlattice Cold Stage device: developed and fabricated high performance Superlattice unicouple and multicouple with high aspect (L/A) ratio elements with superior performance

The Hi-Z Technology MultiWatt Quantum Well Thermoelectric research effort investigates use of materials employing Quantum Well (QW) technology, which could increase thermoelectric conversion efficiencies to more than 25 percent. The objective is to develop QW materials from their current proof-of-principle status to a prototype level for higher temperature space power systems. 30 to 50-micron thick multilayered QW films will be deposited onto 5-micron thick Si substrates via a sputtering process. First year achievements include:

- Hi-Z obtained a new Sputtering machine with $\sim 15 \mathrm{~cm}$ diameter samples and planetary expansion system

- Conducted thermal aging of both $\mathrm{Si} / \mathrm{SiGe}$ and $\mathrm{B}_{4} \mathrm{C} / \mathrm{B}_{9} \mathrm{C}$ QW structures, showing very little change over time even at $600{ }^{\circ} \mathrm{C}$

- $\quad$ Modeling work in progress

- QW Materials have been fabricated on a thick ( 200 micron) substrate (goal is on a 5 micron substrate)

\section{Thermophotovoltaic (TPV)}

The Essential Research, Inc./University of Notre Dame Very High Efficiency (Thermophotovoltaic) TPV Converter research effort investigates application of non-planar TPV cells, which may yield a 50 percent increase in conversion efficiency over state-of-the-art planar TPV technology. For a band gap of $0.6 \mathrm{eV}$, and an assumed 20 percent planar device conversion efficiency, the proposed non-planar cell with sub-micron size $\mathrm{p} / \mathrm{n}$ dot-junctions may yield conversion efficiencies of almost 30 percent, a significant increase over traditional thermoelectrics. Essential Research plans to employ a proprietary technology to produce dot junction geometries (which have been demonstrated to be highly efficient in silicon solar cells) at sub-micron sizes in defect free, lattice mismatched InGaAs on InP substrates. First year achievements include:

- Successfully completed materials and microprocessing development

- Demonstrated 18.5 percent improvement in AM0 (space environment) efficiency of a floating junction cell over a reference planar cell

- However, initial results showed a 1 percent decrease in Voc and a 50 percent increase in dark saturation current density $\left(\mathrm{J}_{0}\right)$. The goal was to produce a dot junction cell with an increase in Voc and an order of magnitude less $\mathrm{J}_{0}$ than with an "identical" planar junction cell. 
The Creare Inc./EMCORE Corp./NASA GRC/Polytechnic University/Oak Ridge National Laboratory Advanced TPV Development effort involves the development of an advanced TPV concept that includes high temperature selective emitters, filters and advanced lattice-mismatched InGaAs PV cells. Creare expects to demonstrate a system conversion efficiency of 15 to 20 percent, a specific power of 10 to $15 \mathrm{~W} / \mathrm{kg}$, and a TRL of 5 . The starting point is the 20 percent efficiency already demonstrated by one of the team members, and their confidence level for further improvement is high. First year achievements include:

- Phase I baseline converter achieved 19 percent efficiency (includes tandem plasma-dielectric filter with a $4 \times 4$ InGaAs array) with $\mathrm{T}_{\text {emitter }}$ at $1077^{\circ} \mathrm{C}$ and $\mathrm{T}_{\text {cell }}$ at $27^{\circ} \mathrm{C}$

- Plasma sprayed tungsten emitter fabrication demonstrated

- NRL Damage Dose Displacement method used to assess neutron degradation using protons

- Facility prepared for materials evaporation and deposition testing

The EDTEK Inc./University of Houston TPV Radioisotope Power Conversion Technology development effort involves development of a TPV concept that could provide a 3 to 4 -fold improvement in system efficiency over current thermoelectric-based radioisotope generators. The key technological innovations are a novel integrated cell front contact and concentrator scheme, a unique tuned Frequency Selective Surface (FSS) filter array, a noncontaminating emitter, and a unique scheme for thermal management that will allow a reduction in total system mass by about a factor of 3 . If successful, the projected system efficiency could achieve a maximum of 23 percent. First year achievements include:

- Phase I baseline converter achieved 20 percent efficiency (includes FSS filter, prism, and GaSb array) with $\mathrm{T}_{\text {emitter }}$ at $1050^{\circ} \mathrm{C}$ and $\mathrm{T}_{\text {cell }}$ at $18^{\circ} \mathrm{C}$

- $\quad$ Single-layer filter model has been completed

- Aperture Array Lithography demonstrated for FSS bandpass filter fabrication

- Installation of new nano-positioning stage for precise and more efficient filter fabrication

\section{Stirling and Brayton}

The Cleveland State University/University of Minnesota/Gedeon Associates/Sunpower/STC Stirling Convertor Regenerator Microfabrication research effort focuses on reducing Stirling regenerator pressure drop losses and improving structural reliability through use of micro-fabrication processes, while maintaining or improving upon current regenerator thermal performance. Regenerator design is a key consideration in achieving high performance with both Stirling and the related thermoacoustic machines. This effort will address the significant performance improvements achieved through better understanding of regenerator flow fields and manifold effects. It will also utilize these results to work with Stirling designers and micro-fabricators to build an advanced regenerator that achieves the potential gains. First year achievements include:

- Developed a microscale regenerator design based on state of the art analytic and computational tools, projecting a 6 to 9 percent increase in power for a Stirling engine

- Improved structure for higher reliability, which permits use of progressive materials for strength and corrosion resistance

- Selected a manufacturing vendor and a microfabrication technique

- Completed EDM tools for fabricating micro regenerator which meet specifications

- Designed a Large-Scale Mock-up (LSMU) and began fabrication

The Sunpower/Boeing Rocketdyne/Cleveland State University/University of Minnesota Advanced Stirling Convertor development effort will develop a Stirling converter that has considerably improved performance characteristics over current systems. The key technologies from this effort are hydrostatic gas bearings, a moving magnet linear alternator, a high temperature heater head, and a controller with active power factor correction. The proposed effort will demonstrate a converter that is superior to the Stirling Radioisotope Generator (SRG) unit that DOE and NASA are currently developing for flight. The efficiency of the proposed unit is 32 percent (compared to 23 percent for the SRG), and the convertor specific power is nearly $100 \mathrm{~W}_{\mathrm{e}} / \mathrm{kg}$ (compared to $15 \mathrm{~W}_{\mathrm{e}} / \mathrm{kg}$ for the SRG). First year achievements include: 
- The Phase I Frequency Test-Bed (FTB) convertor achieved the highest efficiency 36 percent (engine + alternator) for any free-piston Stirling $=54$ percent of Carnot $\left(\mathrm{T}_{\text {hot }}=650{ }^{\circ} \mathrm{C}, \mathrm{T}_{\text {cold }}=30^{\circ} \mathrm{C}, \mathrm{T}_{\text {hot }} / \mathrm{T}_{\text {cold }}=3\right.$ )

- The Advanced Stirling Convertor ASC-1 (Phase II, bolted flange design) design has been initiated, and is projecting $\sim 40$ percent efficiency (engine + alternator $)=60$ percent of Carnot $\left(\mathrm{T}_{\text {hot }}=850{ }^{\circ} \mathrm{C}, \mathrm{T}_{\text {cold }}=90^{\circ} \mathrm{C}\right.$, $\mathrm{T}_{\text {hot }} / \mathrm{T}_{\text {cold }}=3$ )

- Identified high temperature heater head materials to allow operation at $850^{\circ} \mathrm{C}$ and developed joining and processing techniques (Reference SRG at $650^{\circ} \mathrm{C}$ )

- Conducted reliability assessment to identify key elements which are now part of a reliability test plan

The Creare Inc./Ball Aerospace/Boeing Rocketdyne/Jackson \& Tull Turbo-Brayton Power System (TBPS) development will develop a high-efficiency ( 25 to 36 percent), low-mass $(6.7 \mathrm{~kg})$ turbo-Brayton power conversion system. Key to this effort is application of micro-machining and fabrication techniques to build a very small, compact turbine-alternator that can operate at $1200 \mathrm{~K}$. The effort draws on the talents of a multidisciplinary team that will design, fabricate and test a representative converter system. First year achievements include:

- Completed converter design with projected efficiency of $>20$ percent $\left(\mathrm{T}_{\text {hot }}=777{ }^{\circ} \mathrm{C}, \mathrm{T}_{\text {cold }}=59^{\circ} \mathrm{C}\right)$

- Identified Turbo-Alternator-Compressor materials and fabricated miniature rotor including turbine, compressor, shaft, and magnet

- Demonstrated 200 start/stop cycles using spin test rig without wear

- Designed silicon heat exchanger recuperator, fabricated components, and developed subscale recuperator for proof-of-concept testing. An annular recuperator concept has also been designed.

\section{Conclusion}

This paper described the Radioisotope Power Conversion Technology NASA Research Announcement, and its focus to advance the development of radioisotope power conversion technologies to provide higher efficiencies and specific powers than existing systems. Results from the ten RPCT NRA contracts in the areas of Brayton, Stirling, thermoelectric (TE), and thermophotovoltaic (TPV) power conversion technology efforts have been summarized. The advances from these RPCT NRA efforts will enable more cost effective science missions for NASA.

\section{References}

Department of Energy, Space Radioisotope Power Systems, “Advanced Radioisotope Power Systems Fact Sheet," (2002) http://www.ne.doe.gov/space/arpsfact.pdf, accessed November 2004.

Department of Energy, Office of Nuclear Energy, Science, and Technology, "Nuclear Power in Space," DOE/NE0071, (1990) http://www.ne.doe.gov/pubs/npspace.pdf, accessed November 2004.

NASA, Amendment to NASA Research Announcement NRA 02-OSS-01-RPCT, "Research Opportunities in Space Science 2002 entitled Radioisotope Power Conversion Technology," (2002) http://research.hq.nasa.gov/code_s/nra/current/NRA-05-OSS-01-rpct/index.html, accessed November 2004.

NASA, "NASA VISION MISSIONS Nuclear Systems Program Office Project Prometheus," (2003)

http://spacescience.nasa.gov/missions/npsfactsheet.pdf, accessed November 2004. 


\begin{tabular}{|c|c|c|c|}
\hline \multicolumn{3}{|c|}{ REPORT DOCUMENTATION PAGE } & $\begin{array}{l}\text { Form Approved } \\
\text { OMB No. 0704-0188 }\end{array}$ \\
\hline \multicolumn{4}{|c|}{ 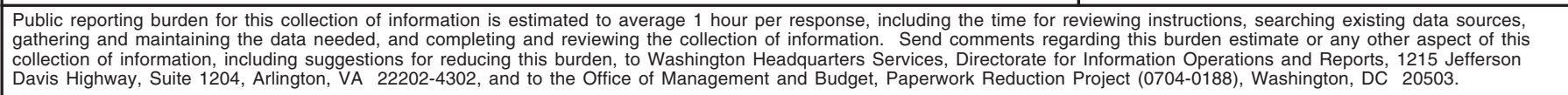 } \\
\hline 1. AGENCY USE ONLY (Leave blank) & $\begin{array}{r}\text { 2. REPORT DATE } \\
\text { November } 2005\end{array}$ & $\begin{array}{r}\text { 3. REPORT TYPE AN } \\
\mathrm{T}\end{array}$ & $\begin{array}{l}\text { D DATES COVERED } \\
\text { echnical Memorandum }\end{array}$ \\
\hline \multicolumn{3}{|c|}{$\begin{array}{l}\text { 4. TITLE AND SUBTITLE } \\
\text { NASA Radioisotope Power Conversion Technology NRA Overview }\end{array}$} & \multirow{2}{*}{\begin{tabular}{|l} 
5. FUNDING NUMBERS \\
WBS-22-972-90-01
\end{tabular}} \\
\hline \multicolumn{3}{|l|}{ 6. AUTHOR(S) } & \\
\hline \multicolumn{3}{|c|}{$\begin{array}{l}\text { National Aeronautics and Space Administration } \\
\text { John H. Glenn Research Center at Lewis Field } \\
\text { Cleveland, Ohio } 44135-3191\end{array}$} & $\begin{array}{l}\text { 8. PERFORMING ORGANIZATION } \\
\text { REPORT NUMBER }\end{array}$ \\
\hline \multicolumn{3}{|c|}{$\begin{array}{l}\text { National Aeronautics and Space Administration } \\
\text { Washington, DC 20546-0001 }\end{array}$} & $\begin{array}{l}\text { 10. SPONSORING/MONITORING } \\
\text { AGENCY REPORT NUMBER }\end{array}$ \\
\hline \multicolumn{4}{|c|}{$\begin{array}{l}\text { 11. SUPPLEMENTARY NOTES } \\
\text { Prepared for the Space Technology and Applications International Forum (STAIF-2005) sponsored by the University of } \\
\text { New Mexico's Institute for Space and Nuclear Power Studies (UNM-ISNPS), Albuquerque, New Mexico, February } \\
\text { 13-17, 2005. Responsible person, David J. Anderson, e-mail: David.J.Anderson@ nasa.gov, organization code PS, } \\
\text { 216-433-8709. }\end{array}$} \\
\hline \multicolumn{3}{|c|}{$\begin{array}{l}\text { 12a. DISTRIBUTION/AVAILABILITY STATEMENT } \\
\text { Unclassified - Unlimited } \\
\text { Subject Categories: } 20 \text { and } 44\end{array}$} & 12b. DISTRIBUTION CODE \\
\hline \multicolumn{4}{|l|}{ 13. ABSTRACT (Maximum 200 words) } \\
\hline \multicolumn{4}{|c|}{$\begin{array}{l}\text { The focus of the National Aeronautics and Space Administration's (NASA) Radioisotope Power Systems (RPS) } \\
\text { Development program is aimed at developing nuclear power and technologies that would improve the effectiveness of } \\
\text { space science missions. The Radioisotope Power Conversion Technology (RPCT) NASA Research Announcement (NRA) } \\
\text { is an important mechanism through which research and technology activities are supported in the Advanced Power } \\
\text { Conversion Research and Technology project of the Advanced Radioisotope Power Systems Development program. The } \\
\text { purpose of the RPCT NRA is to advance the development of radioisotope power conversion technologies to provide higher } \\
\text { efficiencies and specific powers than existing systems. These advances would enable a factor of two to four decrease in the } \\
\text { amount of fuel and a reduction of waste heat required to generate electrical power, and thus could result in more cost } \\
\text { effective science missions for NASA. The RPCT NRA selected advanced RPS power conversion technology research and } \\
\text { development proposals in the following three areas: innovative RPS power conversion research, RPS power conversion } \\
\text { technology development in a nominal } 100 \mathrm{~W}_{\mathrm{e}} \text { scale; and, milliwatt/multi-watt RPS (mWRP) power conversion research. } \\
\text { Ten RPCT NRA contracts were awarded in } 2003 \text { in the areas of Brayton, Stirling, thermoelectric (TE), and } \\
\text { thermophotovoltaic (TPV) power conversion technologies. This paper will provide an overview of the RPCT NRA, a } \\
\text { summary of the power conversion technologies approaches being pursued, and a brief digest of first year accomplishments. }\end{array}$} \\
\hline
\end{tabular}

Public reporting burden for this collection of information is estimated to average 1 hour per response, including the time for reviewing instructions, searching existing data sources,

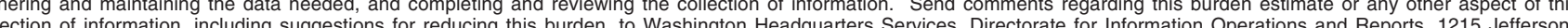
avis Highway, Suite 1204, Arlington, VA 22202-4302, and to the Office of Management and Budget, Paperwork Reduction Project (0704-0188), Washington, DC 20503.

Technical Memorandum

NASA Radioisotope Power Conversion Technology NRA Overview

THOR(S)

David J. Anderson

PERFORMING ORGANIZATION

E-15303

John H. Glenn Research Center at Lewis Field

Cleveland, Ohio 44135-3191

. SPONSORING/MONITORING

NASA TM-2005-213981

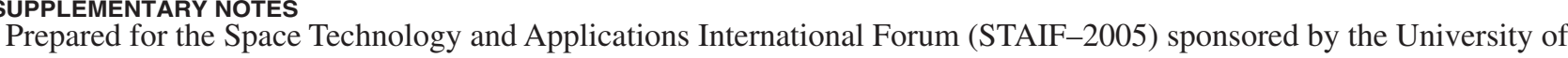

New Mexico's Institute for Space and Nuclear Power Studies (UNM-ISNPS), Albuquerque, New Mexico, February

13-17, 2005. Responsible person, David J. Anderson, e-mail: David.J.Anderson@ nasa.gov, organization code PS,

Unclassified - Unlimited

Subject Categories: 20 and 44

Available electronically at http://gltrs.grc.nasa.gov

ABSTRACT (Maximum 200 words)

The focus of the National Aeronautics and Space Administration's (NASA) Radioisotope Power Systems (RPS)

Development program is aimed at developing nuclear power and technologies that would improve the effectiveness of space science missions. The Radioisotope Power Conversion Technology (RPCT) NASA Research Announcement (NRA) is an important mechanism through which research and technology activities are supported in the Advanced Power Conversion Research and Technology project of the Advanced Radioisotope Power Systems Development program. The purpose of the RPCT NRA is to advance the development of radioisotope power conversion technologies to provide higher amount of fuel and a reduction of waste heat required to generate electrical power, and thus could result in more cost effective science missions for NASA. The RPCT NRA selected advanced RPS power conversion technology research and development proposals in the following three areas: innovative RPS power conversion research, RPS power conversion echnology development in a nominal $100 \mathrm{~W}_{\mathrm{e}}$ scale; and, milliwatt/multi-watt RPS (mWRPS) power conversion research. thermophotovoltaic (TPV) power conversion technologies. This paper will provide an overview of the RPCT NRA, a

14. SUBJECT TERMS
Stirling cycle; Thermoelectric generators; Brayton cycle; Thermoelectricity;

Space missions; Thermophotovoltaic conversion; Energy conversion efficiency; Power convertors; Regenerators

\begin{tabular}{|c|c|c|}
\hline $\begin{array}{c}\text { 17. SECURITY CLASSIFICATION } \\
\text { OF REPORT } \\
\text { Unclassified }\end{array}$ & $\begin{array}{c}\text { 18. SECURITY CLASSIFICATION } \\
\text { OF THIS PAGE } \\
\text { Unclassified }\end{array}$ & $\begin{array}{c}\text { 19. SECURITY CLASSIFICATION } \\
\text { OF ABSTRACT } \\
\text { Unclassified }\end{array}$ \\
\hline
\end{tabular}

NSN 7540-01-280-5500

\begin{tabular}{l} 
15. NUMBER OF PAGES \\
14 \\
16. PRICE CODE \\
20. LIMITATION OF ABSTRACT \\
\hline
\end{tabular}

Standard Form 298 (Rev. 2-89)

Prescribed by ANSI Std. Z39-18 298-102 

